\title{
How annulus defects can act as initiation sites for herniation
}

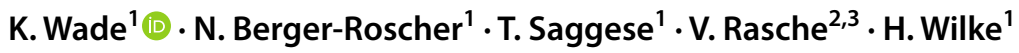

Received: 20 July 2021 / Revised: 13 January 2022 / Accepted: 25 January 2022 / Published online: 16 February 2022

(c) The Author(s) 2022

\begin{abstract}
Purpose Both posture and loading rate are key factors in the herniation process and can determine the mechanism of disc failure. The aim of this study was to test the hypothesis that disruption visible with HR-MRI post-testing corresponds with microstructural features and further elucidate the mechanism by which this disruption weakens the disc. This will enable us to gain new insights into the herniation process.

Methods Thirty ovine lumbar spinal segments were subjected to combinations of four loading conditions $\left(0-12^{\circ}\right.$ flexion, $0-9^{\circ}$ lateral bending, $0-4^{\circ}$ axial rotation, $0-1500 \mathrm{~N}$ axial compression) for 1000 loading cycles at $2 \mathrm{~Hz}$ in a dynamic disc loading simulator. The discs were scanned in an ultra-high field MRI (11.7 T) then examined using brightfield microscopy to examine their microstructure.

Results Four discs herniated and seven discs suffered nucleus displacement. These discs contained pre-existing defects in the central posterior annulus. Generally, following testing discs contained more posterior annulus disruption, Microstructural investigation revealed there was clear correspondence between HR-MRI and microstructural observations, and that the midouter annular-endplate junction had failed in all discs examined in this study.

Conclusions While all discs suffered outer annulus damage, only the discs containing pre-existing defects herniated. These pre-existing defects weakened the inner and mid annulus, allowing herniation to occur once the mid and outer annular wall was compromised. We propose this can occur during the degenerative cascade.
\end{abstract}

Keywords Disc herniation $\cdot$ Complex loading $\cdot$ Annulus fibrosus $\cdot$ Disc prolapse $\cdot$ Microstructure

\section{Introduction}

It seems logical that certain discs are more likely to herniate than others because they contain defects which weaken their annular wall. Indeed, it has been suggested that this may be the reason that herniation is common in middle-aged patients whose discs have a weakened annulus but a highly hydrated nucleus [1] and it is well known that artificial defects can act as initiation sites for herniation or degeneration [2-6].

\footnotetext{
H. Wilke

hans-joachim.wilke@uni-ulm.de

1 Trauma Research Center Ulm (ZTF), Institute of Orthopedic Research and Biomechanics, Ulm University, Helmholtzstraße 14, 89081 Ulm, Germany

2 Department of Internal Medicine II, University Hospital Ulm, Ulm, Germany

3 Small Animal MRI, Medical Faculty, Ulm University, Ulm, Germany
}

Both posture and loading rate are known to be key factors in the herniation process $[1,7,8]$. In general, the more severe the posture, the lesser the load required to damage the motion segment. Loading rate must be sufficiently rapid to overcome viscoelastic effects and can also determine whether the disc fails in the mid-annulus or the endplate junction [9-11]. Relatively rapid loading similar to the maximum rate loading can be generated voluntarily $[12,13]$ was recently shown to render the annulus-endplate junction more vulnerable to failure $[11,14,15]$. Both these modes of failure have been observed clinically [9]. Longer-term loading simulating occupational loading is known to cause disc wall failure [16-19] via disruption and limited nucleus displacement in the inner and mid annulus which was recently observed at the microstructural level in the ovine disc [20, 21].

The aim of the present study was to test the hypothesis that disruption visible with HR-MRI post-testing corresponds with microstructural features and further elucidate the mechanism by which this disruption weakens the disc. 
This will enable us to gain new insights into the herniation process.

\section{Methods}

\section{Experimental design}

Thirty lumbar spinal motion segments were gathered from six healthy sheep (age 3-5 years) and divided into five groups (each $n=6$ ); in order to limit the possible influence of vertebral level, the upper and lower lumbar spines were equally represented within groups. All specimens within a group were from different spines (as shown in Table 1) in order to most randomly distribute any potentially degenerate specimens between the groups and ensure an even distribution of spinal levels within each group.

Ovine spines were used due to the strong anatomical [22] and biomechanical $[23,24]$ similarities to the human system. In particular, the trabecular structure of the vertebra indicates that both vertebral columns are subject to axial loading [25]. Previous in vitro studies using ovine tissue $[8,10,11$, $14,21]$ have produced very similar damage morphologies to those carried out using human tissue [7, 19, 26, 27].

\section{Preparation}

Specimens were frozen and stored at $-20^{\circ} \mathrm{C}$ prior to testing. These storage conditions are consistent with those used in this field and have been shown to cause negligible degradation of specimen properties [28-30]. The posterior elements were carefully removed by cutting through the facet joints to provide a clear view of the posterior annulus. Note also that while the posterior elements were removed, the machine was programmed in order to apply these postures about axes passing through the centre of the disc laterally and vertically, and through the posterior third of the disc in the anteropostero direction. These were chosen in order to approximate the physiologic situation though we acknowledge that in reality, this varies due to the facet joints and surrounding musculature $[31,32]$.

\section{Imaging techniques}

Discs were non-destructively imaged before and after testing to enable the influence of pre-existing structure on susceptibility to herniation to be determined. The specimens were thawed at $6{ }^{\circ} \mathrm{C}$ overnight prior to scanning. Imaging was performed in an $11.7 \mathrm{~T} \mu \mathrm{MRI}$ (BioSpec 117/16, Bruker Biospin, Ettlingen, Germany) using an experimental protocol derived from previous experiments (MR method: FLASH, Contrast: T1, Echo time: $3.5 \mathrm{~ms}$, Repetition time: $10.0 \mathrm{~ms}$, Resolution: $100 \mu \mathrm{m}$ isotropic, Slice gap: $100 \mu \mathrm{m}$, FOV: $60 \mathrm{~mm} \times 70 \mathrm{~mm}$, Averages: 1, Acquisition time: $15 \mathrm{~min}$ ) [33]. All data were received with a $40 \mathrm{~mm}$ quadrature transmit/receive coil.

\section{Further preparation for testing}

Screws were placed in the vertebral bodies to embed the motion segment in the PMMA (Technovit 3040, HeraeusKulzer, Wehrheim, Germany) followed by storage at $-20^{\circ} \mathrm{C}$. Prior to testing, the specimens were thawed at $6{ }^{\circ} \mathrm{C}$ for $12 \mathrm{~h}$ [8] (Fig. 1).

\section{Test protocols}

A compressive load of $130 \mathrm{~N}$ (typical spinal load for a standing sheep [34]) was applied for 15 min to precondition the specimens $[8,14,23,34]$. Specimens were stored in

Table 1 Overview of the loading conditions applied to each group and the motion segments assigned to each group

\begin{tabular}{|c|c|c|c|c|c|}
\hline Load component & Group 1 w/o FL & Group 2 w/o LB & Group 3 w/o AR & Group 4 all combined & $\begin{array}{l}\text { Group } 5 \text { all } \\
\text { combined, rapid } \\
\text { loading }\end{array}$ \\
\hline FL & - & $X$ & $X$ & $X$ & $X$ \\
\hline LB & $\mathrm{X}$ & - & $X$ & $X$ & $X$ \\
\hline AR & $X$ & $X$ & - & $X$ & $X$ \\
\hline $\mathrm{AC}$ & $X$ & $X$ & $X$ & $X$ & $X$ \\
\hline \multirow[t]{6}{*}{ Segments } & Spine 1 L5-6 & Spine 1 L4-5 & Spine 1 L2-3 & Spine $1 \mathrm{~L} 1-2$ & Spine 1 L3-4 \\
\hline & Spine 2 L3-4 & Spine 2 L5-6 & Spine 2 L1-2 & Spine 2 L2-3 & Spine 2 L4-5 \\
\hline & Spine 3 L1-2 & Spine 3 L4-5 & Spine 3 L2-3 & Spine 3 L3-4 & Spine 3 L5-6 \\
\hline & Spine 4 L2-3 & Spine 4 L1-2 & Spine 4 L3-4 & Spine 4 L4-5 & Spine 4 L5-6 \\
\hline & Spine 5 L3-4 & Spine 5 L2-3 & Spine 5 L4-5 & Spine 5 L5-6 & Spine 5 L1-2 \\
\hline & Spine 6 L4-5 & Spine 6 L3-4 & Spine 6 L5-6 & Spine 6 L2-3 & Spine 6 L1-2 \\
\hline
\end{tabular}

FL indicates flexion; LB, lateral bending; AR, axial rotation. Note that groups 1-4 had loading applied in $10 \%$ steps over the first 100 cycles of the test while Group 5 was rapidly loaded to the full level of posture sequentially for each axis 
A

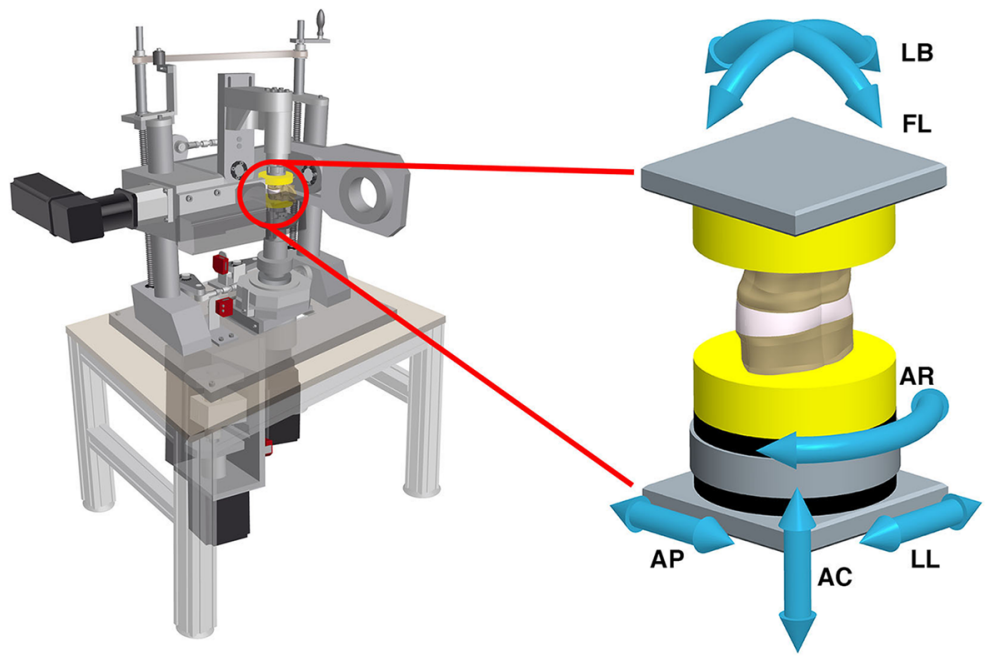

B
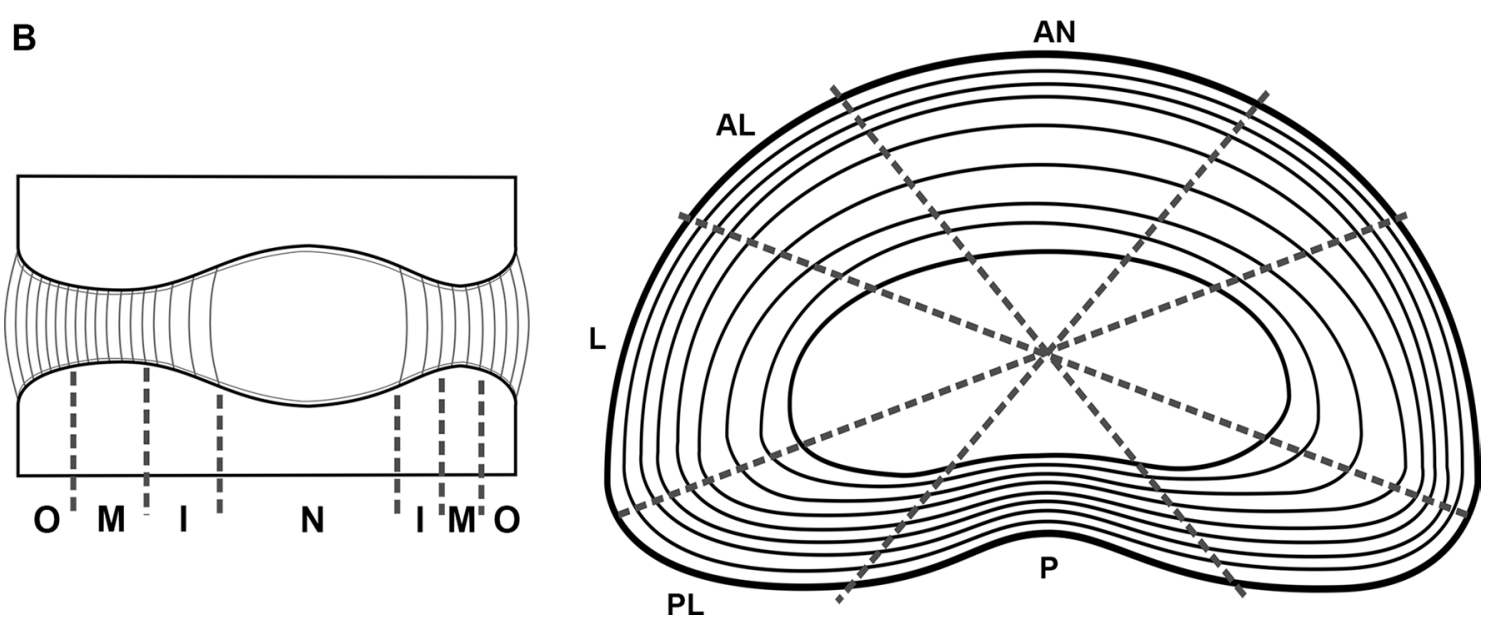

Fig. 1 a Schematic drawing of the experimental setup showing the 6-DOF dynamic spine tester (left) and a mounted view of the motion segment with each potential direction of motion (FL: flexion; LB: lateral bending; AR: axial rotation; AC: axial compression; AP: anteroposterior shear; LL: laterolateral shear) shown. Note that shear was

dampened gauze prior to testing to maintain hydration [31] and were tested at room temperature as is standard practise for short-term acute loading $[7,8,10,11]$. Testing was performed using a complex loading protocol (Table 1). The following loading parameters were used: $0^{\circ}-13^{\circ}$ flexion (FL), $0^{\circ}-10^{\circ}$ right lateral bending (LB), and $0^{\circ}-4^{\circ}$ right axial rotation (AR) combined with $0 \mathrm{~N}-1500 \mathrm{~N}$ of axial compression (AC) at a frequency of $2 \mathrm{~Hz}$ which results in a physiologic loading rate [12-14]. For Groups 1-4, during the first 90 cycles, angles were increased in 10\%-increments with 10 cycles each. For Group 5, each axis was sequentially moved to its maximum, then cyclic loading applied. Samples were subjected to 1000 cycles in total. They were videoed from the posterior direction to detect visible and audible disc failures. Following testing, specimens were refrozen at $-20{ }^{\circ} \mathrm{C}$ prior to reimaging with HR-MRI. kept fixed during this investigation. b Sagittal cross-section showing how the disc can be considered as outer annulus $(\mathrm{O})$, mid annulus (M) inner annulus (I) and nucleus (N) Transverse cross-section showing how the disc is generally subdivided into anterior (AN), anterolateral $(\mathrm{AL})$, lateral $(\mathrm{L})$, posterolateral $(\mathrm{PL})$ and posterior $(\mathrm{P})$ regions

\section{Structural analysis}

Upon examining the HR-MRI images, it was rapidly apparent that many discs contained shadowed, uneven features in the central posterior annulus and following loading the discs either suffered herniation through these features or had developed similar features of their own. We developed a simple scoring system to grade these, in which a feature that spanned $<33 \%$ of the annulus was termed small, between 33 and $66 \%$ termed moderate, and greater than $66 \%$ termed large.

\section{Microstructural analysis techniques}

Following testing, each motion segment was trimmed to isolate the disc and its adjacent endplates, fixed for 7 days in $10 \%$ formalin and decalcified for 21 days in $10 \%$ formic 
acid as in previous studies $[10,11]$. Each sample was then bisected sagittally and cryosectioned to obtain $30 \mu \mathrm{m}$ thick sections in the 'sagittal plane'. Slices were microscopically analysed in their fully hydrated state using brightfield microscopy. With a $0.7 \mathrm{~mm}$ interval, between 12 and 18 sections were examined per half-disc block to enable features to be tracked across the disc. Disc damage was analysed using terminology developed in previous microstructural studies $[20,21]$.

\section{Results}

There is clear correspondence between HR-MRI, macrolevel and microstructural observations of the overall mechanisms of damage to the motion segments. As summarized in Tables 2 and 3, all four discs which herniated or suffered displacement (seven discs) contained a characteristic bell-shaped defect prior to testing (eleven discs in total). Only discs containing such a defect herniated. Four discs suffered overt herniation, with extrusion of nucleus material, and nucleus displacement into the annulus was observed in a further seven discs. All but one disc suffered rupture of the mid-outer annulus region. In general, as the severity of the complex posture increased, the level of damage also increased. All discs emitted crackling noises during testing, this generally occurred between 60 and $90 \%$ of full load, with the exception of the discs tested with immediate application of the full level of posture, which suffered annular failure as flexion was applied. More severe postures were generally associated with higher moments, consistent with Berger-Roscher et al. [14] as shown in Table 3.

An example of a disc which contained a large pre-existing defect and which suffered transligamentous herniation through this irregularity is shown in Fig. 2. Nucleus material was extruded through the defect region in the annular wall in both the transverse and sagittal views, illustrating the complementary nature of each imaging technique. Annulusendplate failure was observed in the mid and outer annulus regions.

An example of a disc which suffered internal displacement of nucleus material is shown in Fig. 3. The pre-existing defect and migration of nucleus material into this can be seen in the HR-MRI images. Damage to the mid and outer annulus-endplate junction is clearly visible in both techniques along with delaminated and ruptured lamellae in the inner annulus. The nucleus material has been displaced into the resulting space in the annulus wall.

Two examples of discs which developed characteristic bell-shaped defects are shown in Figs. 4 and 5. The example in Fig. 4 contained minor disruption in the posterior annulus prior to testing visible with HR-MRI. However, following testing, a clear bell-shaped defect could be seen. When this region was examined microstructurally, firstly mid-outer annulus-endplate failure was clearly visible and the region corresponding to the defect contained ruptured and distorted lamellae. However, there was no substantial displacement of nucleus material in this sample. While the disc in Fig. 5 did not contain irregularities in its posterior annulus prior to testing, following testing a small bell-shaped defect was visible. When sectioned, it also had severe damage to the mid-outer annulus wall. There was minor disruption to the inner annulus wall, corresponding to the region where the bell-shaped defect was observed.

Further examples of the mid and outer annulus damage are shown in Fig. 6. These contained ruptures at the annulusendplate junction, both at the tidemark (boundary between calcified and non-calcified cartilage) and the cement line (cartilage bone interface). Alternate lamellae failure was also observed at the annulus endplate junction.

\section{Discussion}

The results of the present study clearly indicate that discs containing greater levels of pre-existing disruption are more vulnerable to suffering further damage when subjected to severe levels of posture and loading. They also indicate that the HRMRI observations correspond with microstructural observations post-testing. Due to the nature of the loading used in the present study, they provide new insights into how the disc may be vulnerable to herniation that would not be apparent were each technique considered in isolation. We consider the audible observations of failure as the posture was increased to correspond to failure of the mid-outer annulus and therefore that the inner and mid annulus were left to bear load for the remainder of the test. It follows that those discs which suffered herniation did so as a consequence of their inner and mid regions being weakened by the bell-shaped characteristic defects visible under HR-MRI prior to testing.

These test methods were based on numerous previous in-vitro biomechanics studies. Postures were intended to simulate extreme levels of loading and were chosen to be twice those obtained by Wilke et 1997 and Reitmaier et al. where the range of motion of ovine lumbar spinal segments was measured under $3.75 \mathrm{Nm}$ pure moment in each direction without posterior elements [23, 34], while facet joints were removed. Similar levels of posture have been applied to intact motion segments without facet joint failure by other authors $[10,11]$ and the machine used here does impose a centre of rotation approximating that of the facet joints. Freezing and thawing of samples is common practise in biomechanics in order to preserve specimens during collection and preparation and was particularly necessary for this trial given the relatively large number of specimens and numerous imaging and testing methods used. Several 
Table 2 Summary of microstructural analysis of all discs in this study

\begin{tabular}{|c|c|c|c|c|c|c|c|c|c|}
\hline & $\begin{array}{l}\text { pine / } \\
\text { lotion } \\
\text { eg- } \\
\text { lent }\end{array}$ & $\begin{array}{l}\text { HR-MRI before } \\
\text { testing }\end{array}$ & Loading regime & $\begin{array}{l}\text { HR-MRI after } \\
\text { testing }\end{array}$ & Nucleus & Transition zone & Inner & Mid & Outer \\
\hline 1 & $\mathrm{~L} 1-2$ & $\begin{array}{l}\text { Minor general } \\
\text { disruption }\end{array}$ & G4 FL/LB/AR & $\begin{array}{l}\text { Increased disrup- } \\
\text { tion in posterior } \\
\mathrm{AF}\end{array}$ & & & $D_{\text {dist }}$ & $\mathrm{M} / \mathrm{S}$ & $\mathrm{A} / \mathrm{Ec}$ \\
\hline 1 & L2-3 & $\begin{array}{l}\text { Minor general } \\
\text { disruption }\end{array}$ & G3 FL/LB & $\begin{array}{l}\text { Increased disrup- } \\
\text { tion in posterior } \\
\text { AF }\end{array}$ & & & $\mathrm{M} / \mathrm{S}$ & $\mathrm{A} / \mathrm{Ec}$ & $\mathrm{A} / \mathrm{Ec}$ \\
\hline 1 & L3-4 & $\begin{array}{l}\text { Minor general } \\
\text { disruption }\end{array}$ & G5 FL/LB/AR (s) & $\begin{array}{l}\text { Increased disrup- } \\
\text { tion in posterior } \\
\text { AF }\end{array}$ & & & $\mathrm{M} / \mathrm{S}$ & $\mathrm{M} / \mathrm{S}+\mathrm{A} / \mathrm{Et}$ & $\mathrm{A} / \mathrm{Ec}$ \\
\hline 1 & L4-5 & $\begin{array}{l}\text { Minor general } \\
\text { disruption }\end{array}$ & G2 FL/AR & $\begin{array}{l}\text { Increased disrup- } \\
\text { tion in posterior } \\
\mathrm{AF}\end{array}$ & & $D_{\text {dist }}$ & $\mathrm{A} / \mathrm{Ec}$ & $\mathrm{A} / \mathrm{Ec}$ & $\mathrm{A} / \mathrm{Ec}$ \\
\hline 1 & L5-6 & $\begin{array}{l}\text { Minor general } \\
\text { disruption }\end{array}$ & G1 LB/AR & $\begin{array}{l}\text { Increased disrup- } \\
\text { tion in posterior } \\
\mathrm{AF}\end{array}$ & & & $\mathrm{Ec}+D_{\mathrm{dist}}$ & $\mathrm{M} / \mathrm{Sr}$ & $\mathrm{A} / \mathrm{Ec}$ \\
\hline 2 & L1-2 & $\begin{array}{l}\text { Minor general } \\
\text { disruption }\end{array}$ & G3 FL/LB & (no data) & & & $D_{\text {lam }}$ & $\mathrm{M} / \mathrm{Sr}$ & $\mathrm{A} / \mathrm{Ev}$ \\
\hline 2 & L2-3 & $\begin{array}{l}\text { Small characteris- } \\
\text { tic defect }\end{array}$ & G4 FL/LB/AR & Displacement & $N_{\text {out }}$ & $\mathrm{M} / \mathrm{S}$ & $\mathrm{A} / \mathrm{E}+\mathrm{M} / \mathrm{S}$ & $\mathrm{A} / \mathrm{Et}+\mathrm{M} / \mathrm{S}$ & $\mathrm{A} / \mathrm{Ec}+\mathrm{M} / \mathrm{S}$ \\
\hline 2 & L3-4 & Regular annulus & G1 LB/AR & $\begin{array}{l}\text { Moderate charac- } \\
\text { teristic defect }\end{array}$ & & & $D_{\text {dist }}$ & $\mathrm{M} / \mathrm{Sr}$ & $\mathrm{A} / \mathrm{Ec}$ \\
\hline 2 & L4-5 & $\begin{array}{l}\text { Small characteris- } \\
\text { tic defect }\end{array}$ & G5 FL/LB/AR (s) & Displacement & & $N_{\text {in }}$ & $D_{\text {dist }}$ & $\mathrm{A} / \mathrm{Ec}$ & $\mathrm{A} / \mathrm{Ev}$ \\
\hline 2 & L5-6 & $\begin{array}{l}\text { Minor general } \\
\text { disruption }\end{array}$ & G2 FL/AR & $\begin{array}{l}\text { Increased disrup- } \\
\text { tion in posterior } \\
\mathrm{AF}\end{array}$ & & $D_{\text {dist }}$ & $\mathrm{A} / \mathrm{Ec}$ & $\mathrm{A} / \mathrm{Et}+\mathrm{M} / \mathrm{S}$ & $\mathrm{A} / \mathrm{Et}+\mathrm{M} / \mathrm{S}$ \\
\hline 3 & $\mathrm{~L} 1-2$ & $\begin{array}{l}\text { Small characteris- } \\
\text { tic defect }\end{array}$ & G1 LB/AR & Displacement & $D_{\text {dist }}$ & $D_{\text {dist }}$ & $D_{\text {dist }}$ & $\mathrm{A} / \mathrm{Ec}+D_{\text {dist }}$ & $\mathrm{A} / \mathrm{Ec}$ \\
\hline 3 & $\mathrm{~L} 2-3$ & $\begin{array}{l}\text { Small characteris- } \\
\text { tic defect }\end{array}$ & G3 FL/LB & Displacement & $D_{\text {dist }}$ & $D_{\text {dist }}$ & $D_{\text {dist }}$ & $\mathrm{A} / \mathrm{Ec}+D_{\text {dist }}$ & $\mathrm{A} / \mathrm{Ev}$ \\
\hline 3 & L3-4 & $\begin{array}{l}\text { Moderate charac- } \\
\text { teristic defect }\end{array}$ & G4 FL/LB/AR & Displacement & $N_{\text {in }}$ & $N_{\text {in }}$ & $\mathrm{M} / \mathrm{S}$ & $\mathrm{A} / \mathrm{Ec}+D_{\text {dist }}$ & $\mathrm{A} / \mathrm{Ec}$ \\
\hline 3 & L4-5 & $\begin{array}{l}\text { Large characteris- } \\
\text { tic defect }\end{array}$ & G2 FL/AR & Herniation & $N_{\text {hern }}$ & $N_{\text {hern }}$ & $\mathrm{A} / \mathrm{Ec}+\mathrm{M} / \mathrm{S}+\mathrm{V}(\mathrm{PL})$ & $\mathrm{A} / \mathrm{Et}+\mathrm{M} / \mathrm{S}$ & $\mathrm{A} / \mathrm{Ec}+\mathrm{M} / \mathrm{S}$ \\
\hline 3 & L5-6 & $\begin{array}{l}\text { Large characteris- } \\
\text { tic defect }\end{array}$ & G5 FL/LB/AR (s) & Herniation & $N_{\text {hern }}$ & $N_{\text {hern }}$ & $\mathrm{A} / \mathrm{Ec}+\mathrm{M} / \mathrm{S}+\mathrm{V}(\mathrm{PL})$ & $\mathrm{A} / \mathrm{Et}+\mathrm{M} / \mathrm{S}$ & $\mathrm{A} / \mathrm{Et}+\mathrm{M} / \mathrm{S}$ \\
\hline 4 & $\mathrm{~L} 1-2$ & $\begin{array}{l}\text { Minor disruption } \\
\text { in posterior AF }\end{array}$ & G2 FL/AR & $\begin{array}{l}\text { Moderate charac- } \\
\text { teristic defect }\end{array}$ & $D_{\text {dist }}$ & $D_{\text {dist }}$ & $D_{\text {dist }}$ & $\mathrm{A} / \mathrm{Ev}$ & $\mathrm{A} / \mathrm{Ev}$ \\
\hline 4 & L2-3 & $\begin{array}{l}\text { Very minor } \\
\text { disruption in } \\
\text { posterior AF }\end{array}$ & G1 LB/AR & $\begin{array}{l}\text { Small characteris- } \\
\text { tic defect }\end{array}$ & $D_{\text {dist }}$ & $N_{\text {in }}$ & $N_{\text {mid }}$ & $\mathrm{M} / \mathrm{Sr}$ & $\mathrm{A} / \mathrm{Et}$ \\
\hline 4 & L3-4 & $\begin{array}{l}\text { Moderate disrup- } \\
\text { tion in posterior } \\
\text { AF }\end{array}$ & G3 FL/LB & $\begin{array}{l}\text { Endplate fracture } \\
\text { despite pre- } \\
\text { existing damage }\end{array}$ & $D_{\text {dist }}$ & $N_{\text {in }}$ & $D_{\text {dist }}+D_{\text {lam }}$ & $\mathrm{A} / \mathrm{Ev}$ & $\mathrm{A} / \mathrm{Ev}$ \\
\hline 4 & L4-5 & $\begin{array}{l}\text { Moderate general } \\
\text { disruption in } \\
\text { posterior AF }\end{array}$ & G4 FL/LB/AR & $\begin{array}{l}\text { Increased disrup- } \\
\text { tion in posterior } \\
\text { AF }\end{array}$ & $D_{\text {dist }}$ & $N_{\text {in }}$ & $D_{\text {dist }}+D_{\text {lam }}$ & $\mathrm{A} / \mathrm{Ev}$ & $\mathrm{A} / \mathrm{Ev}$ \\
\hline 4 & L5-6 & $\begin{array}{l}\text { Moderate disrup- } \\
\text { tion in posterior } \\
\text { AF }\end{array}$ & G5 FL/LB/AR (s) & $\begin{array}{l}\text { Increased disrup- } \\
\text { tion in posterior } \\
\text { AF }\end{array}$ & $D_{\text {dist }}$ & $D_{\text {dist }}$ & $D_{\text {dist }}+D_{\text {lam }}$ & $\mathrm{A} / \mathrm{Ev}$ & $\mathrm{A} / \mathrm{Ev}$ \\
\hline 5 & L1-2 & $\begin{array}{l}\text { Minor disruption } \\
\text { in posterior AF }\end{array}$ & G5 FL/LB/AR (s) & $\begin{array}{l}\text { Increased disrup- } \\
\text { tion in posterior } \\
\text { AF }\end{array}$ & $D_{\text {dist }}$ & $N_{\text {in }}$ & $D_{\text {dist }}+N_{\text {mid }}$ & $\mathrm{A} / \mathrm{Ev}$ & $\mathrm{A} / \mathrm{Ec}+\mathrm{M} / \mathrm{S}$ \\
\hline
\end{tabular}


Table 2 (continued)

\begin{tabular}{|c|c|c|c|c|c|c|c|c|c|}
\hline & $\begin{array}{l}\text { pine / } \\
\text { lotion } \\
\text { eg- } \\
\text { ent }\end{array}$ & $\begin{array}{l}\text { HR-MRI before } \\
\text { testing }\end{array}$ & Loading regime & $\begin{array}{l}\text { HR-MRI after } \\
\text { testing }\end{array}$ & Nucleus & Transition zone & Inner & Mid & Outer \\
\hline 5 & L2-3 & $\begin{array}{c}\text { Minor disruption } \\
\text { in posterior AF, } \\
\text { Schmorl's node }\end{array}$ & G2 FL/AR & $\begin{array}{l}\text { Schmorl's node } \\
\text { got larger, } \\
\text { increased } \\
\text { disruption in } \\
\text { posterior AF }\end{array}$ & $D_{\text {dist }}$ & $D_{\text {dist }}$ & $D_{\text {dist }}+\mathrm{M} / \mathrm{S}$ & $\mathrm{A} / \mathrm{Ev}$ & $\mathrm{A} / \mathrm{Et}+\mathrm{M} / \mathrm{S}$ \\
\hline 5 & L3-4 & $\begin{array}{l}\text { Small characteris- } \\
\text { tic defect }\end{array}$ & G1 LB/AR & Displacement & $D_{\text {dist }}$ & $N_{\text {in }}$ & $D_{\text {dist }}$ & $D_{\text {dist }}$ & $\mathrm{A} / \mathrm{Ec}$ \\
\hline 5 & L4-5 & $\begin{array}{l}\text { Small characteris- } \\
\text { tic defect }\end{array}$ & G3 FL/LB & $\begin{array}{l}\text { Subligamentous } \\
\text { herniation }\end{array}$ & $N_{\text {out }}$ & $N_{\text {out }}$ & $N_{\text {out }}$ & $\mathrm{A} / \mathrm{Ev}$ & $\mathrm{A} / \mathrm{Ev}$ \\
\hline 5 & L5-6 & $\begin{array}{l}\text { Moderate charac- } \\
\text { teristic defect }\end{array}$ & G4 FL/LB/AR & Herniation & $N_{\text {out }}$ & $N_{\text {out }}$ & $N_{\text {out }}$ & $\mathrm{A} / \mathrm{Ev}$ & $\mathrm{A} / \mathrm{Ev}$ \\
\hline 6 & L1-2 & $\begin{array}{r}\text { Minor disruption } \\
\text { in posterior AF }\end{array}$ & G5 FL/LB/AR (s) & $\begin{array}{l}\text { Moderate charac- } \\
\text { teristic defect }\end{array}$ & $N_{\text {in }}$ & $N_{\text {in }}$ & $D_{\text {dist }}+\mathrm{M}$ & $\mathrm{A} / \mathrm{Ec}$ & $\mathrm{A} / \mathrm{Ec}$ \\
\hline 6 & $\mathrm{~L} 2-3$ & $\begin{array}{r}\text { Minor disruption } \\
\text { in posterior } \mathrm{AF}\end{array}$ & G4 FL/LB/AR & $\begin{array}{l}\text { Small characteris- } \\
\text { tic defect }\end{array}$ & $N_{\text {in }}$ & $N_{\text {in }}$ & $D_{\text {dist }}+\mathrm{M}$ & $\mathrm{A} / \mathrm{Ec}$ & $\mathrm{A} / \mathrm{Ec}$ \\
\hline 6 & L3-4 & $\begin{array}{l}\text { Minor disruption } \\
\text { in posterior AF }\end{array}$ & G2 FL/AR & $\begin{array}{l}\text { Small characteris- } \\
\text { tic defect }\end{array}$ & $D_{\text {dist }}$ & $D_{\text {dist }}$ & $D_{\text {dist }}$ & $D_{\text {lam }}$ & $\mathrm{A} / \mathrm{Ec}+\mathrm{M} / \mathrm{S}$ \\
\hline 6 & L4-5 & $\begin{array}{l}\text { Minor disruption } \\
\text { in posterior AF }\end{array}$ & G1 LB/AR & $\begin{array}{l}\text { Small characteris- } \\
\text { tic defect }\end{array}$ & & & $D_{\text {dist }}$ & $D_{\text {dist }}$ & $D_{\text {lam }}$ \\
\hline 6 & L5-6 & $\begin{array}{l}\text { Small characteris- } \\
\text { tic defect }\end{array}$ & G3 FL/LB & Displacement & $M_{\mathrm{in}}$ & $M_{\mathrm{in}}$ & $D_{\text {dist }}$ & $\mathrm{A} / \mathrm{Ev}$ & $\mathrm{A} / \mathrm{Ev}$ \\
\hline
\end{tabular}

Analysis was conducted in accordance with earlier paper

Firstly, the damage location was identified radially by region (see Fig. 1), i.e. nucleus (N), inner annulus (I), mid annulus (M), outer annulus (O), or on the boundary between these regions i.e. (N/I, I/M, M/O). Nucleus displacement was classified as either distorted with respect to its original state, or migration to inner $\left(N_{\text {in }}\right)$, mid $\left(N_{\text {mid }}\right)$, outer $\left(N_{\text {out }}\right)$ or herniated $\left(N_{\text {hern }}\right)$. Annulus wall damage was then further classified with respect to the three main types of damage (D) based on the microstructural observations i.e. delaminations between lamellae $\left(D_{\text {lam }}\right)$, internal distortions $\left(D_{\text {dist }}\right)$, and disc/endplate tears $\left(D_{\text {tears }}\right)$. The latter were further classified by aspect (Fig. 1b) i.e. superior (s) or inferior (i), and axial depth i.e. surface of endplate (Es), middle or tidemark (Et), cement line (Ec), or vertebral body (Ev) [15]

Table 3 Summarised loading results for all groups showing audible indications of failure, peak moments, numbers of pre-existing defects and overall failure mode of the discs

\begin{tabular}{llllll}
\hline Load component & Group 1 LB/AR & Group 2 FL/AR & Group 3 FL/LB & Group 4 FL/LB/AR & Group 5 FL/LB/AR (s) \\
\hline Crackling noise (cycle) & $71(70-100)$ & $84(80-90)$ & $76(50-90)$ & $70(30-103)$ & $(0)^{*}$ \\
Peak moments FL (Nm) & $24.8(15.2-42.5)$ & $22.1(13.3-54.3)$ & $37.6(27.5-48.3)$ & $40.7(24.1-58.5)$ & $31.7(12.8-42.9)$ \\
Peak moments LB (Nm) & $22.1(19-39.1)$ & $16.1(13-23.7)$ & $24.9(19.5-32.9)$ & $19.4(14.8-32.9)$ & $13.3(10.1-23.7)$ \\
Peak moments AR (Nm) & $14.1(12.4-16.3)$ & $13.2(9.1-14.1)$ & $5(1.9-6.9)$ & $11.8(9.5-16.7)$ & $13.2(9.1-14.1)$ \\
Pre-existing defects & 2 & 1 & 3 & 3 & 2 \\
Herniations & 0 & 1 & 1 & 1 & 1 \\
Displacement & 2 & 0 & 2 & 2 & 1 \\
New defects & 3 & 2 & 0 & 1 & 1 \\
\hline
\end{tabular}

FL indicates flexion; LB, lateral bending; AR, axial rotations

*Note that the full levels of load and posture were applied at cycle 1, thus audible indications of failure occurred immediately in this group

investigations indicate that freeze-thaw cycles do not substantially influence specimen mechanical properties, and our own experience with similar investigations of fresh and frozen tissue indicates that freeze-thaw cycles do not influence the microstructure of the disc, at least in terms of the relatively large-scale features considered in this study.

Consider the severe transligamentous herniation shown in Fig. 2, from a disc which contained a large pre-existing defect. We can see that the outer annulus has failed and that 

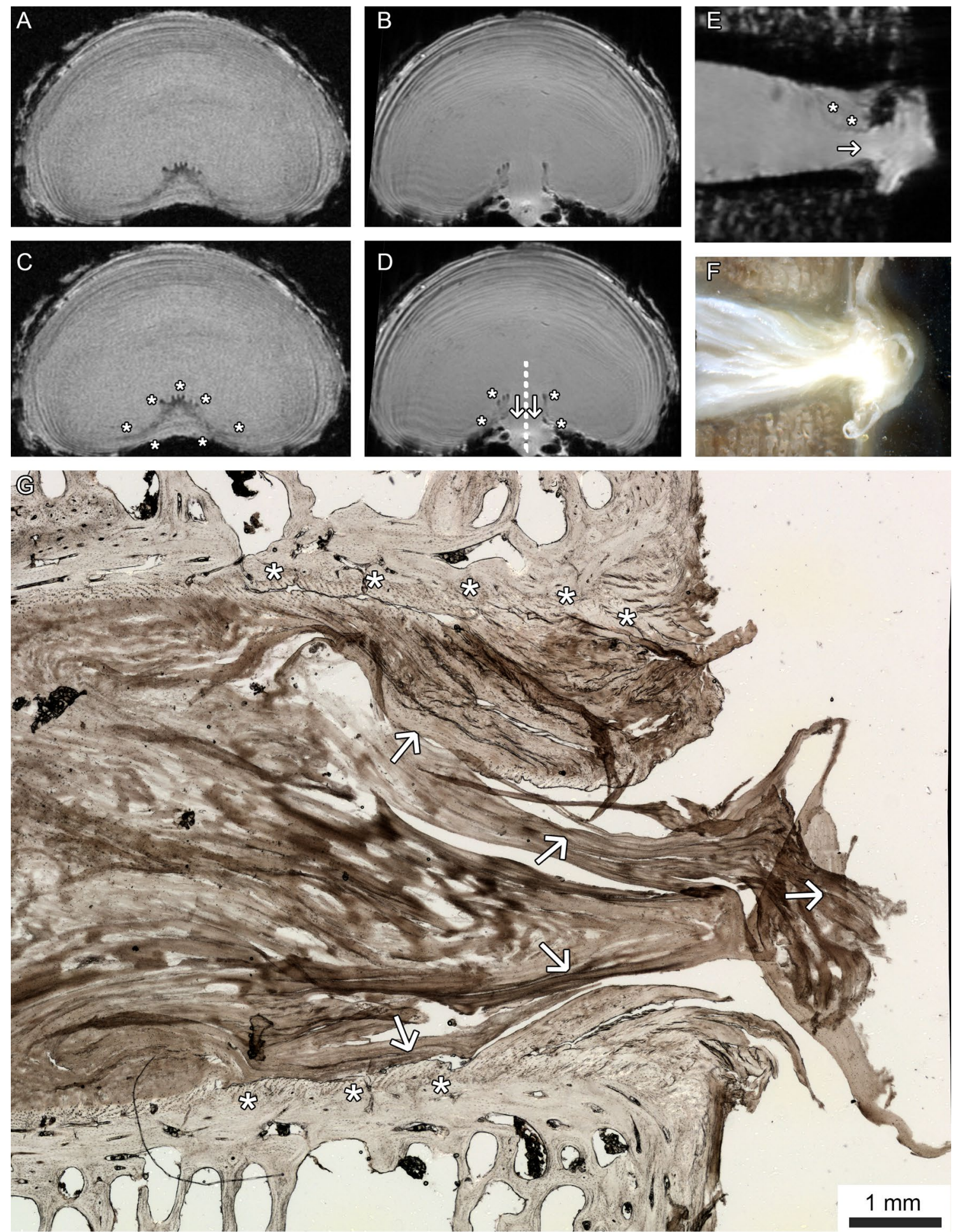

Fig. 2 Shows a disc which suffered transligamentous herniation during testing. a A transverse HR-MRI image showing a large bellshaped defect in the posterior annulus prior to testing. b Following testing, disc material was extruded through this region. c, d Defect region indicated with stars and flow of herniated material indicated by arrows, respectively. e Sagittal HR-MRI view through central pos- terior region (dashed line in $\mathbf{d}$ ) showing the herniation region. f Corresponding sagittal macro image which clearly shows the displaced nucleus material. g Corresponding microstructural image. The damaged annulus-endplate junction regions are highlighted by the stars, and the flow of nucleus material is indicated by the arrows 

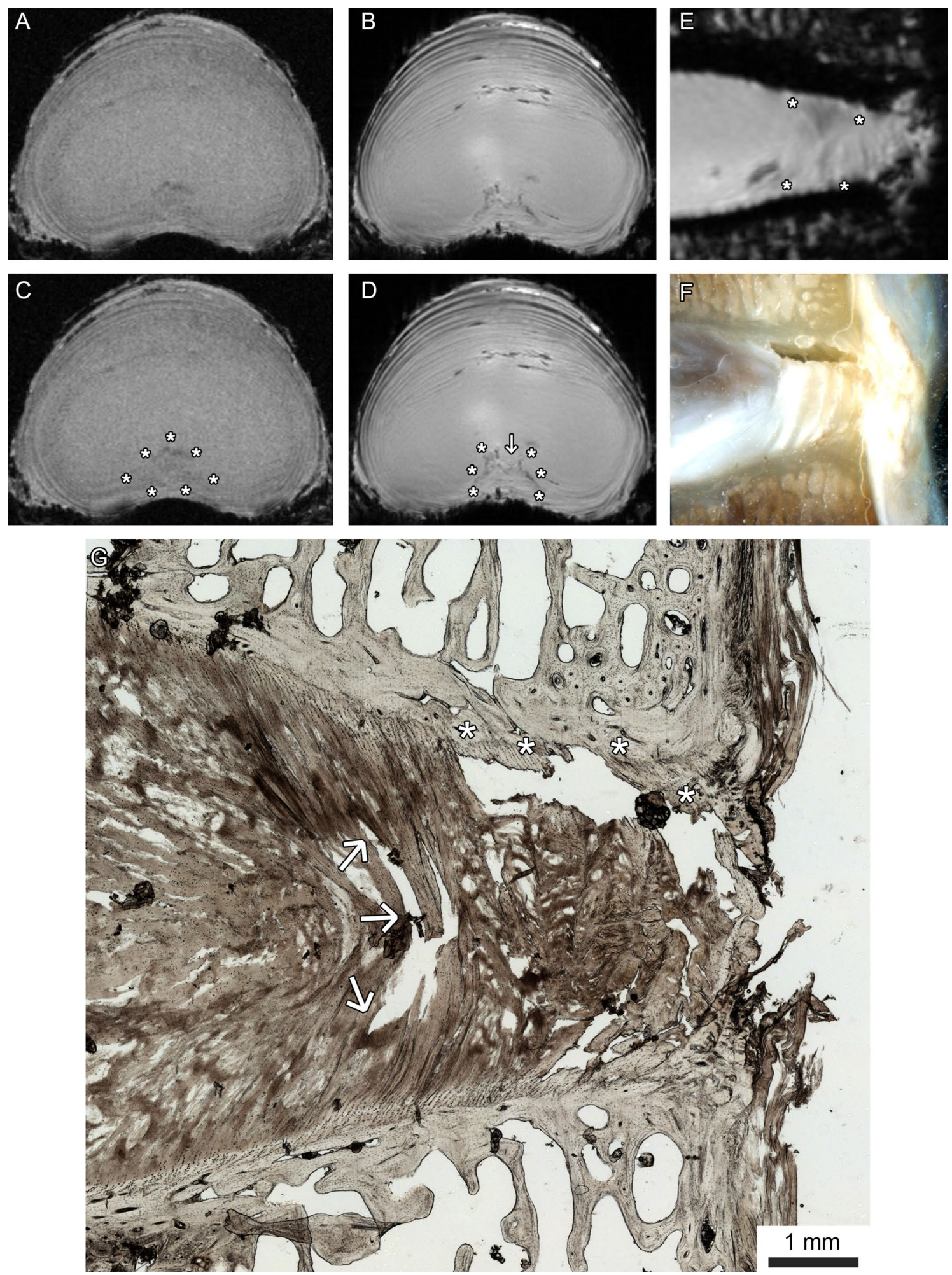

Fig. 3 Shows a disc which suffered nucleus displacement during testing. a A transverse HR-MRI image showing a moderate bell-shaped defect in the posterior annulus prior to testing. b Following testing, disc material was displaced into this region. c, d Defect region boundary indicated with stars and flow of displaced material indicated by arrows, respectively. e Sagittal HR-MRI view through central posterior region (dashed line in d) showing this region with the displaced material boundary indicated with stars. f Corresponding sagittal macro image which shows the annulus-endplate rupture and displaced nucleus material. g Corresponding microstructural image. The damaged annulus-endplate junction regions are highlighted by the stars, and the displaced nucleus material is indicated by the arrows 

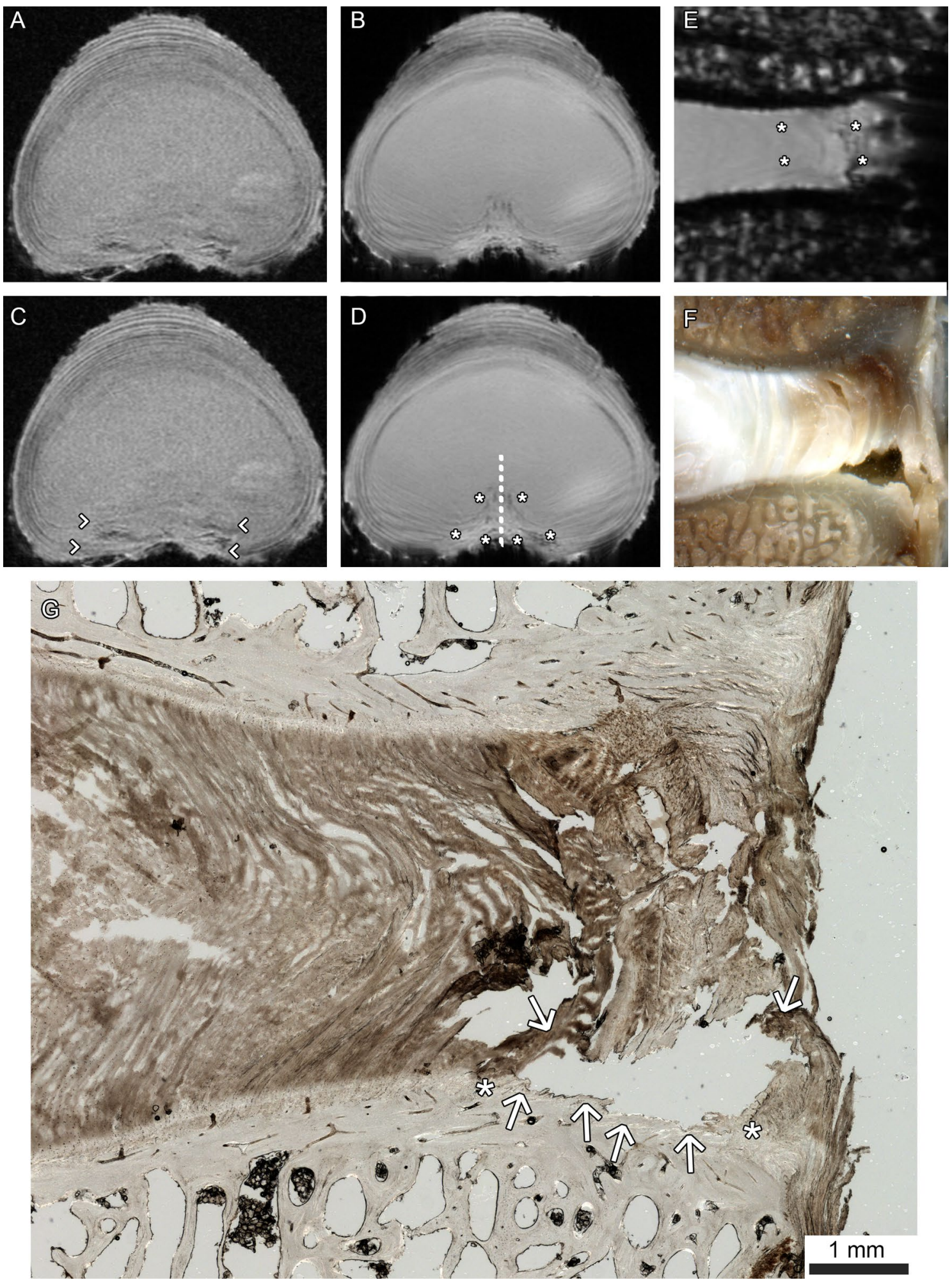

Fig. 4 Shows a disc which developed a bell-shaped defect during testing. a A transverse HR-MRI image showing minor disruption in the posterior annulus prior to testing. b Following testing, a bell-shaped defect can be seen in this region. c, $\mathbf{d}$ Disruption indicated by arrowheads and defect boundary indicated with stars. e Sagittal HR-MRI view through central posterior region (dashed line in d) showing this region with the defect region bounded by stars. f Corresponding sagittal macro image which shows the annulus-endplate rupture. $\mathbf{g}$ Corresponding microstructural image. The damaged annulus-endplate junction regions are highlighted by the stars, and the ruptures and delaminations in the defect region are indicated by the arrows 


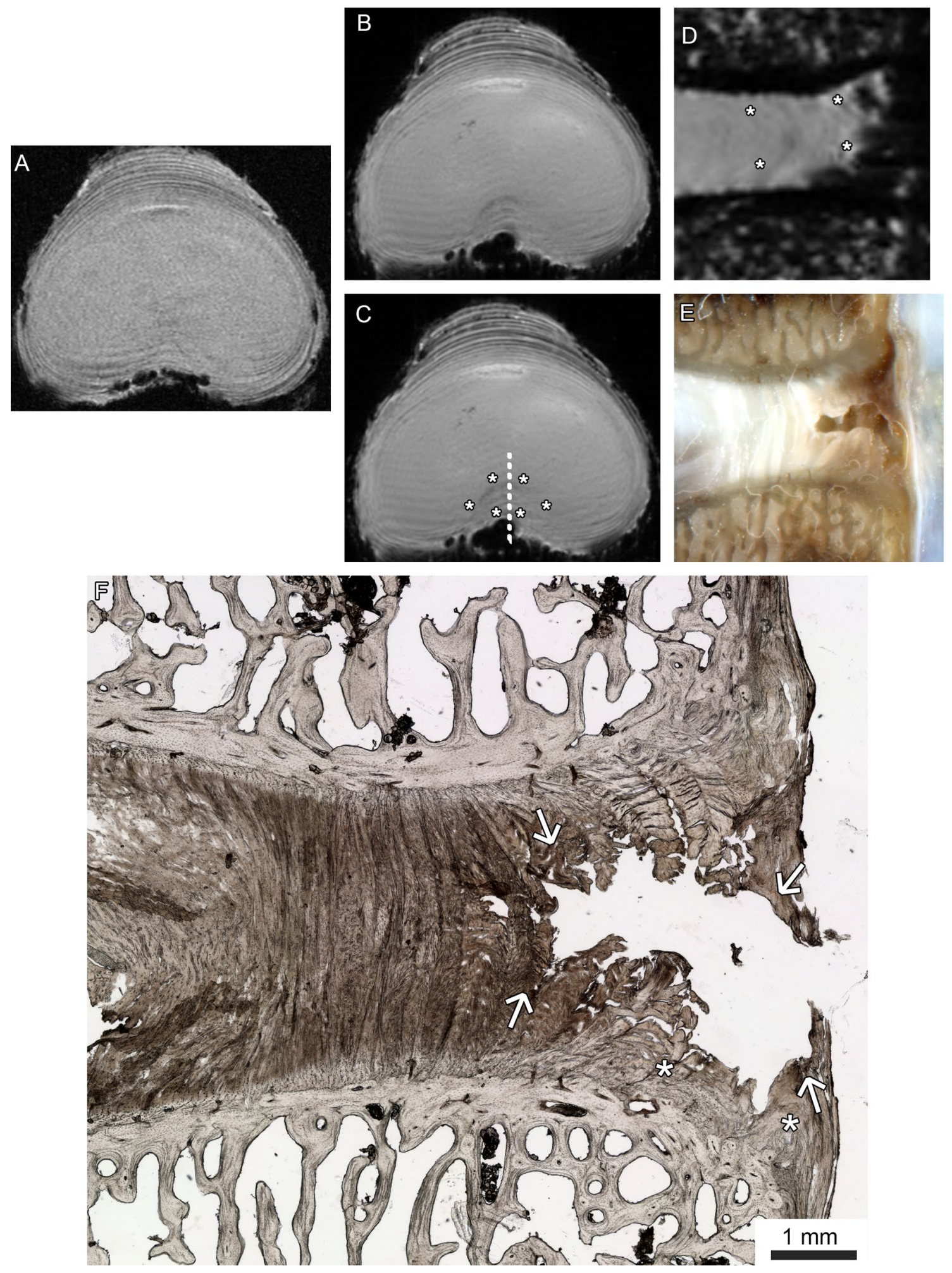

Fig. 5 Shows a disc which developed a bell-shaped defect during testing. a A transverse HR-MRI image showing a disc with no irregularities in its posterior annulus prior to testing. b Following testing, a bell-shaped defect can be seen in this region. c Shows the defect region bounded by stars. d Sagittal HR-MRI view through central posterior region (dashed line in b) showing this region with the defect region bounded by stars. e Corresponding sagittal macro image which shows the annulus-endplate rupture. $\mathbf{f}$ Corresponding microstructural image. The damaged annulus-endplate junction regions are highlighted by the stars, and the ruptured lamellae in the defect region are indicated by the arrows 

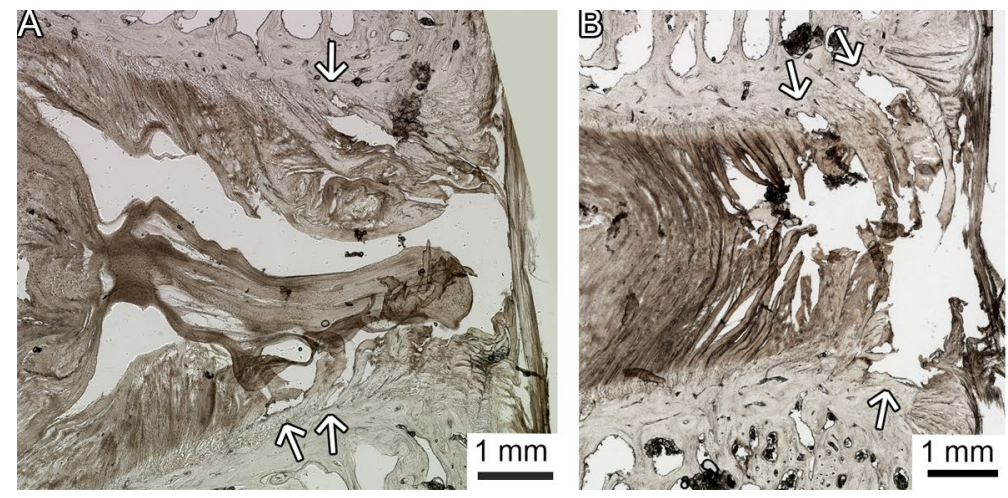

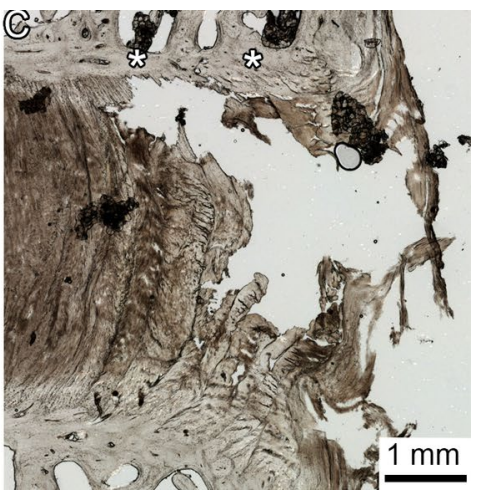

Fig. 6 In these examples, when the outer annulus-endplate failure is examined closely, damage to alternate lamellae can be seen as indicated by the arrows in (a) and (b). The section in $\mathbf{c}$ shows a disc which suffered extensive rupture of the annulus-endplate junction in the region bounded by the stars

case, this less severely weakened structure still retains some of its self-sealing ability (as suggested by early in-vitro investigations $[39,40])$ and is able to prevent full herniation of the disc, at least under the loading conditions in this study.

In discs containing less obvious or no pre-existing defects (Figs. 4 and 5 respectively) defects were still observed with HR-MRI following testing. These correspond to microstructural observations of ruptures and delamination in the inner and mid-annulus regions implying that these defects are a consequence of loading. This morphology is consistent with recent observations of discs subjected to cyclic loading [20, 21] providing further evidence that repetitive cyclic loading can cause damage to accumulate within the disc due to its limited ability to repair given the rate of matrix turnover being several years or more $[41,42]$ thus increasing its vulnerability to herniation. Correspondence between defect severity and severity of the resulting herniation in the present study also supports this point.

Based on these results, we propose that acute loading can lead to herniation by the sequence of events shown in Fig. 7. If, as in the present study, the disc suffers failure of the outer annulus, the inner annulus will then be required to contain the nucleus if herniation is to be prevented. If the inner annulus is weakened, the disc will therefore herniate. Our results in Figs. 4 and 5 indicate that mechanical loading is capable of producing features similar in appearance to the pre-existing bell-shaped defects consisting of broken and distorted lamellae.

These results support the theory proposed by Adams that middle-aged discs with a compromised annulus but hydrated nucleus are vulnerable to herniation $[1,7,36]$. Explaining what might be responsible for these defects in the first place is an intriguing question outside the original scope of this study. Clearly, mechanical loading can exacerbate the defects, as the number of defects increased following loading in the present study. Genetic predisposition could also play an important role with a less severely weakened inner and mid annulus. In this 


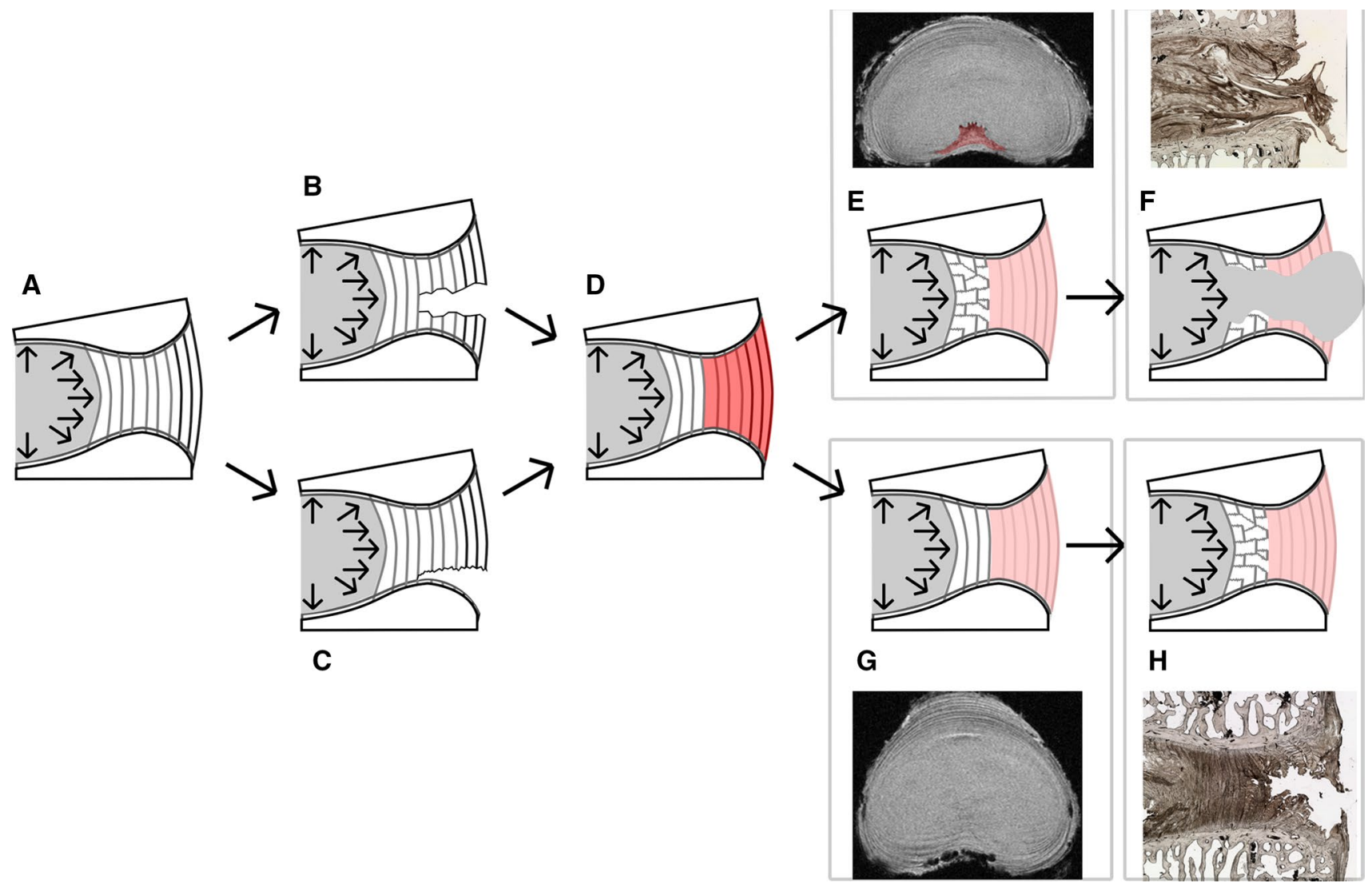

Fig. 7 Schematic representing the sequence of failure indicated by the present results. a healthy disc, with an intact annulus. Repeated exposure to complex posture in steps drives it beyond posture the rigid (more rigid) mid-outer layers can accommodate and these fail, by a combination of $\mathbf{b}$ midspan or $\mathbf{c}$ annular endplate failure. As shown by

in this process; as was shown by the Twin Spine Study [43-46]. In the context of these results, we speculate that some individuals may have incomplete lamellae or other similar features in the annulus which act as stress risers for defect growth.

Interestingly, similar features were observed histologically in a study of middle-aged human discs [47]. We suggest that if these discs were scanned via HR-MRI, that similar defects to those in the present study would be observed. Further, such delamination and rupture within the layers of the inner and mid annulus could in itself be painful, initiate the degenerative cascade [48] or when combined with rehydration and acute loading even initiate herniation in itself. Clinically, while disc bulging and herniation are factors linked with back pain, substantial levels of disc bulging and herniation have been reported in asymptomatic patients and this increases with age. For example, approximately onethird of asymptomatic subjects had a substantial abnormality such as a herniated or bulging disc, or stenosis [49] when imaged under MRI. Similarly, a study of symptomatic and asymptomatic populations found that $24 \%$ of asymptomatic patients had discs with a high-intensity zone, compared the red shading in $\mathbf{d}$, this mid-outer annulus is now unable to contain the contents of the disc. Thus, discs with a compromised inner annulus herniated $\mathbf{e}, \mathbf{f}$ while discs with a healthy inner annulus did not suffer herniation $\mathbf{g}, \mathbf{h}$

with $59 \%$ in symptomatic patients, concluding that highintensity zones alone did not reliably indicate symptomatic disc disruption [50]. A more recent clinical study indicated that the central $(10 \%)$ or paracentral $(82 \%)$ regions of discs undergoing microdiscectomy had suffered herniation, which would correspond to those regions expected to be affected by characteristic defects [9].

Limitations of this study relate to it being an in-vitro study based on animal tissue. By design, this study investigates acute, short term cyclically loaded tissue, which means that its results will not fully replicate the situation occurring in vivo where biological processes such as inflammation and repair can occur [41, 42]. While the use of well-accepted animal models $[22,23,25,51]$ enables the use of relatively young, consistent samples without extensive degeneration, it does mean that caution needs to be used when translating these results to human tissue. Future work could include imaging similar unloaded spines to determine what such defects may look like if not subjected to the acute loading in the present study. Biochemical analysis could yield insights regarding defect formation or progression. Findings should 
also be confirmed in human tissue. Since imaging results of the present study indicate that these defects begin in the inner regions of the disc wall, interventions to prevent this form of progression to herniation will likely be challenging to develop as they would need to cause repair of the avascular, highly loaded inner disc region.

\section{Conclusions}

All but one of the discs in the present study suffered failure of the mid and outer annulus-endplate junction, yet only the discs which contained characteristic pre-existing defects suffered herniation.

These pre-existing defects weakened the inner and mid annulus, allowing herniation to occur once the mid and outer annular wall was compromised.

This failure of the mid and outer annulus was consistent with that observed in other studies using similar loading rates and postures and adds further evidence for this failure being a consequence of compliance imbalance at the hardsoft interface between the structures.

Examination of those discs which developed features appearing similar to the pre-existing defects under microMRI during testing revealed that these regions had become distorted and disrupted. This is likely a consequence of the repetitive motion they had been subjected to during testing. We propose that such damage occurs in life and is associated with the degenerative process.

Acknowledgements We have no relevant conflicts of interest which could have influenced this work. We gratefully acknowledge funding from the German Research Foundation (DFG) Project WI 1352/14-3. Dr. Wade gratefully acknowledges funding from the Alexander von Humboldt Foundation. The authors would like to thank the Ulm University Centre for Translational Imaging MoMAN for its support. We thank Anne Subgang, Marija Josipovic and Laura Schmidt for their assistance in preparing and scanning the discs.

Funding Open Access funding enabled and organized by Projekt DEAL.

\section{Declaration}

Conflict of interest The authors declare that they have no conflict of interest.

Open Access This article is licensed under a Creative Commons Attribution 4.0 International License, which permits use, sharing, adaptation, distribution and reproduction in any medium or format, as long as you give appropriate credit to the original author(s) and the source, provide a link to the Creative Commons licence, and indicate if changes were made. The images or other third party material in this article are included in the article's Creative Commons licence, unless indicated otherwise in a credit line to the material. If material is not included in the article's Creative Commons licence and your intended use is not permitted by statutory regulation or exceeds the permitted use, you will need to obtain permission directly from the copyright holder. To view a copy of this licence, visit http://creativecommons.org/licenses/by/4.0/.

\section{References}

1. Adams MA (2004) Biomechanics of back pain. Acupunct Med 22:178-188

2. Iatridis JC, Michalek AJ, Purmessur D, Korecki CL (2009) Localized intervertebral disc injury leads to organ level changes in structure, cellularity, and biosynthesis. Cell Mol Bioeng 2:437-447. https://doi.org/10.1007/s12195-009-0072-8

3. Schollum ML, Appleyard RC, Little CB, Melrose J (2010) A detailed microscopic examination of alterations in normal anular structure induced by mechanical destabilization in an ovine model of disc degeneration. Spine 35:1965-1973. https://doi. org/10.1097/BRS.0b013e3181e0f085

4. Melrose J, Ghosh P, Taylor TKF, Hall A, Osti OL, VernonRoberts B, Fraser RD (1992) A longitudinal study of the matrix changes induced in the intervertebral disc by surgical damage to the annulus fibrosus. J Orthop Res 10:665-676

5. Masuda K, Aota Y, Muehleman C, Imai Y, Okuma M, Thonar EJ, Andersson GB, An HS (2005) A novel rabbit model of mild, reproducible disc degeneration by an anulus needle puncture: correlation between the degree of disc injury and radiological and histological appearances of disc degeneration. Spine 30:5-14

6. Osti OL, Vernon-Roberts B, Fraser RD (1990) 1990 Volvo award in experimental studies: anulus tears and intervertebral disc degeneration: An experimental study using an animal model. Spine 15:762-767

7. Adams MA, Hutton WC (1982) Prolapsed intervertebral disc: a hyperflexion injury. Spine 7:184-191

8. Wilke HJ, Kienle A, Maile S, Rasche V, Berger-Roscher N (2016) A new dynamic six degrees of freedom disc-loading simulator allows to provoke disc damage and herniation. Eur Spine J 25:1363-1372. https://doi.org/10.1007/s00586-016-4416-5

9. Rajasekaran S, Bajaj N, Tubaki V, Kanna RM, Shetty AP (2013) ISSLS prize winner: the anatomy of failure in lumbar disc herniation: an in vivo, multimodal, prospective study of 181 subjects. Spine 38:1491-1500

10. Wade KR, Robertson PA, Thambyah A, Broom ND (2014) How healthy discs herniate: a biomechanical and microstructural study investigating the combined effects of compression rate and flexion. Spine 39:1018-1028

11. Wade KR, Robertson PA, Thambyah A, Broom ND (2015) 'Surprise' loading in flexion increases the risk of disc herniation due to annulus-endplate junction failure: a mechanical and microstructural investigation. Spine 40:891-901

12. Consmuller T, Rohlmann A, Weinland D, Druschel C, Duda G, Taylor W (2012) Velocity of lordosis angle during spinal flexion and extension. PLoS ONE 7:e50135. https://doi.org/10.1371/ journal.pone.0050135

13. Dolan P, Adams MA (1993) The relationship between EMG activity and extensor moment generation in the erector spinae muscles during bending and lifting activities. J Biomech 26:513-522

14. Berger-Roscher N, Casaroli G, Rasche V, Villa T, Galbusera F, Wilke HJ (2017) Influence of complex loading conditions on intervertebral disc failure. Spine 42:E78-E85. https://doi.org/10. 1097/brs.0000000000001699

15. Veres SP, Robertson PA, Broom ND (2010) ISSLS prize winner: How loading rate influences disc failure mechanics: a 
microstructural assessment of internal disruption. Spine 35:18971908. https://doi.org/10.1097/BRS.0b013e3181d9b69e

16. Yates JP, McGill SM (2011) The effect of vibration and posture on the progression of intervertebral disc herniation. Spine 36:386392. https://doi.org/10.1097/BRS.0b013e3181d2cece

17. Gregory DE, Callaghan JP (2011) Does vibration influence the initiation of intervertebral disc herniation?: an examination of herniation occurrence using a porcine cervical disc model. Spine 36:E225-E231. https://doi.org/10.1097/BRS.0b013e3181d89094

18. Callaghan JP, McGill SM (2001) Intervertebral disc herniation: Studies on a porcine model exposed to highly repetitive flexion/ extension motion with compressive force. Clin Biomech 16:28-37

19. Adams MA, Hutton WC (1985) Gradual disc prolapse. Spine 10:524-531

20. Schollum ML, Wade KR, Robertson PA, Thambyah A, Broom ND (2018) A microstructural investigation of disc disruption induced by low frequency cyclic loading. Spine 43:E132-E142

21. Wade KR, Schollum ML, Robertson PA, Thambyah A, Broom ND (2016) ISSLS prize winner: vibration really does disrupt the disc: a microanatomical investigation. Spine 41:1185-1198. https://doi. org/10.1097/brs.0000000000001594

22. Wilke HJ, Kettler A, Wenger KH, Claes LE (1997) Anatomy of the sheep spine and its comparison to the human spine. Anat Rec 247:542-555

23. Wilke HJ, Kettler A, Claes LE (1997) Are sheep spines a valid biomechanical model for human spines? Spine 22:2365-2374

24. Schmidt H, Reitmaier S (2013) Is the ovine intervertebral disc a small human one? a finite element model study. J Mech Behav Biomed Mater 17:229-241. https://doi.org/10.1016/j.jmbbm. 2012.09.010

25. Smit TH (2002) The use of a quadruped as an in vivo model for the study of the spine-biomechanical considerations. Eur Spine J 11:137-144

26. Adams MA, Hutton WC (1981) The relevance of torsion to the mechanical derangement of the lumbar spine. Spine 6:241-247

27. Farfan HF, Cossette JW, Robertson GH, Wells RV, Kraus H (1970) The effects of torsion on the lumbar intervertebral joints: the role of torsion in the production of disc degeneration. J Bone Joint Surg Am 3:468-497

28. Nachemson A (1960) Lumbar intradiscal pressure. experimental studies on post-mortem material. Acta Orthop Scand Suppl 43:1-104

29. Panjabi MM, Krag M, Summers D, Videman T (1985) Biomechanical time-tolerance of fresh cadaveric human spine specimens. J Orthop Res 3:292-300

30. Smeathers JE, Joanes DN (1988) Dynamic compressive properties of human lumbar intervertebral joints: a comparison between fresh and thawed specimens. J Biomech 21:425-433

31. Yoshioka T, Tsuji H, Hirano N, Sainoh S (1990) Motion characteristic of the normal lumbar spine in young adults: Instantaneous axis of rotation and vertebral center motion analyses. J Spinal Disord 3:103-113

32. Pearcy MJ, Bogduk N (1988) Instantaneous axes of rotation of the lumbar intervertebral joints. Spine 13:1033-1041

33. Berger-Roscher N, Galbusera F, Rasche V, Wilke H-J (2015) Intervertebral disc lesions: visualisation with ultra-high field MRI at 11.7 T. Eur Spine J 24:2488-2495. https://doi.org/10. 1007/s00586-015-4146-0

34. Reitmaier S, Schmidt H, Ihler R, Kocak T, Graf N, Ignatius A, Wilke HJ (2013) Preliminary investigations on intradiscal pressures during daily activities: an in vivo study using the merino sheep. PLoS ONE 8:e69610. https://doi.org/10.1371/journal.pone. 0069610
35. Schmidt H, Kettler A, Heuer F, Simon U, Claes L, Wilke HJ (2007) Intradiscal pressure, shear strain, and fiber strain in the intervertebral disc under combined loading. Spine 32:748-755. https://doi.org/10.1097/01.brs.0000259059.90430.c2

36. Adams MA, Dolan P (2012) Intervertebral disc degeneration: evidence for two distinct phenotypes. J Anat 221:497-506. https:// doi.org/10.1111/j.1469-7580.2012.01551.x

37. Veres SP, Robertson PA, Broom ND (2010) The influence of torsion on disc herniation when combined with flexion. Eur Spine J 19:1468-1478. https://doi.org/10.1007/s00586-010-1383-0

38. Wade KR, Schollum ML, Robertson PA, Thambyah A, Broom ND (2017) A more realistic disc herniation model incorporating compression, flexion and facet-constrained shear: a mechanical and microstructural analysis. Part I: low rate loading. Eur Spine J 26:2616-2628

39. Brinckmann P (1986) Injury of the annulus fibrosus and disc protrusions. an in vitro investigation on human lumbar discs. Spine 11:149-153

40. Markolf KL, Morris JM (1974) The structural components of the intervertebral disc. A study of their contributions to the ability of the disc to withstand compressive forces. J Bone Jt Sur-Series A 56:675-687

41. Sivan SS, Hayes AJ, Wachtel E, Caterson B, Merkher Y, Maroudas A, Brown S, Roberts S (2014) Biochemical composition and turnover of the extracellular matrix of the normal and degenerate intervertebral disc. Eur Spine J 23:344-353. https://doi.org/10. 1007/s00586-013-2767-8

42. Kandel R, Roberts S, Urban JPG (2008) Tissue engineering and the intervertebral disc: the challenges. Eur Spine J 17:S480-S491

43. Battié MC, Videman T (2006) Lumbar disc degeneration: Epidemiology and genetics. J Bone Jt Sur-Series A 88:3-9. https://doi. org/10.2106/jbjs.e.01313

44. Battié MC, Videman T, Kaprio J, Gibbons LE, Gill K, Manninen H, Saarela J, Peltonen L (2009) The twin spine study: contributions to a changing view of disc degeneration $\dagger$. Spine J 9:47-59. https://doi.org/10.1016/j.spinee.2008.11.011

45. Battié MC, Videman T, Levalahti E, Gill K, Kaprio J (2007) Heritability of low back pain and the role of disc degeneration. Pain 131:272-280. https://doi.org/10.1016/j.pain.2007.01.010

46. Battié MC, Videman T, Levälahti E, Gill K, Kaprio J (2008) Genetic and environmental effects on disc degeneration by phenotype and spinal level: a multivariate twin study. Spine 33:2801-2808

47. Walmsley R (1953) The development and growth of the intervertebral disc. Edinb Med J 60:341-364

48. Kirkaldy-Willis WH (1983) Managing low back pain. Churchill Livington, Edinburgh

49. Boden SD, Davis DO, Dina TS, Patronas NJ, Wiesel SW (1990) Abnormal magnetic-resonance scans of the lumbar spine in asymptomatic subjects. a prospective investigation. J Bone Joint Surg Am 72:403-408

50. Carragee EJ, Paragioudakis SJ, Khurana S (2000) Lumbar highintensity zone and discography in subjects without low back problems. Spine 25:2987-2992

51. Alini M, Eisenstein SM, Ito K, Little C, Kettler AA, Masuda K, Melrose J, Ralphs J, Stokes I, Wilke HJ (2008) Are animal models useful for studying human disc disorders/degeneration? Eur Spine J 17:2-19

Publisher's Note Springer Nature remains neutral with regard to jurisdictional claims in published maps and institutional affiliations. 